MODERNISASI PENDIDIKAN DI INDONESIA

April 2014, 3(1): $25-51$

\title{
SEBUAH PERSPEKTIF SOSIOLOGIS TERHADAP DUNIA PENDIDIKAN DI INDONESIA
}

Ankarlina Pandu Primadata dan Dwi Kasi Kusumawati ${ }^{1}$

\begin{abstract}
Abstrak
Krisis multidimensi yang melanda Indonesia sejak tahun 1997 telah membawa dampak yang luar biasa pada mutu sumber daya manusia (SDM) Indonesia dan juga pada mutu pendidikan di Indonesia. Anthony Giddens menjelaskan konsep modernitas dalam "The Juggernaut Of Modernity". Giddens menjelaskan bahwa modernitas layaknya sebuah kendaraan besar yang akan terus melaju, menggiring masyarakat untuk terus berlari menuju masa depan. Pendidikan dan kemiskinan adalah dua hal yang saling terkait. Pendidikan seharusnya menjadi hak bagi setiap orang tanpa memandang kaya-miskin seseorang. Namun kenyataannya, pendidikan yang seharusnya menjadi jalur bagi masyarakat miskin untuk dapat memperbaiki kehidupannya, nyatanya tidak dapat berbuat apa-apa ketika orang-orang miskin tersebut justru tersingkirkan darinya dan tidak dapat menggapainya. Ketidakadilan dalam dunia pendidikan semakin terlihat jelas dengan adanya sistematisasi pendidikan, dimana akhirnya terjadi gap antara kelompok orangorang kaya dan kelompok orang-orang miskin dalam dunia pendidikan.
\end{abstract}

Kata Kunci: Pendidikan, kesenjangan kaya dan miskin.

\section{A. Wajah Pendidikan Indonesia}

Krisis multidimensi yang melanda Indonesia sejak tahun 1997 telah membawa dampak yang luar biasa pada mutu sumber daya manusia (SDM) Indonesia dan juga pada mutu pendidikan di Indonesia. Hal tersebut terlihat dari indikator secara makro, yakni pencapaian Human Development Index (HDI) dan indikator secara mikro, seperti misalnya kemampuan dalam hal membaca dan menulis. Pada tahun 2005, HDI Indonesia menduduki peringkat 110 dari 177 negara di dunia. Bahkan peringkat tersebut semakin menurun dari tahun-tahun sebelumnya. HDI Indonesia tahun 1997 adalah 99, lalu tahun 2002 menjadi 102, kemudian tahun 2004 merosot kembali menjadi 111 (Human Development Report 2005, UNDP). Pada tahun 2011, peringkat HDI Indonesia semakin menurun yaitu pada peringkat 124 dari 187 negara. Menurut Laporan Bank Dunia $^{2}$ dan studi IEA (International Association for the Evaluation of

\footnotetext{
${ }^{1}$ Mahasiswa Pascasarjana Sosiologi Fakultas Ilmu Sosial dan Politik Universitas Sebelas Maret, 57126

2 Greaney dalam Ilham, Wika Y, 10 Desember 2007. Realita dan Idealisme Pendidikan Nasional. http://scientiarum.com/2007/12/10/potret-pendidikan-nasionalrealita-dan-idealisme/. Diakses pada Sabtu, 29 Desember 2012.
} 
Educational Achievement), di Asia Timur menunjukkan bahwa keterampilan membaca siswa kelas IV SD di Indonesia berada pada peringkat terendah. Ratarata skor tes membaca untuk siswa SD: 75,5 (Hongkong), 74,0 (Singapura), 65,1 (Thailand), 52,6 (Filipina), dan 51,7 (Indonesia). Kondisi anak-anak Indonesia hanya mampu menguasai 30 persen dari materi bacaan dan mereka sulit sekali menjawab soal-soal berbentuk uraian yang memerlukan penalaran. Hal ini disebabkan karena mereka sangat terbiasa dalam menghapal serta mengerjakan soal pilihan ganda. ${ }^{3}$

Persoalan pendidikan yang paling menonjol akhir-akhir ini adalah biaya yang harus dibayar oleh setiap orang tua yang akan atau sedang menyekolahkan anaknya. Tidak semua orang dapat dengan bebas mengenyam pendidikan formal. Data berikut yang dikumpulkan dari berbagai sumber, dapat dijadikan gambaran tentang hal tersebut.

Tabel 1. Biaya pendidikan di beberapa institusi pendidikan.

\begin{tabular}{|l|c|c|c|}
\hline \multicolumn{1}{|c|}{$\begin{array}{c}\text { Institusi } \\
\text { Pendidikan }\end{array}$} & $\begin{array}{c}\text { Tahun } \\
\text { Masuk }\end{array}$ & $\begin{array}{c}\text { Uang } \\
\text { Masuk } \\
\text { (Rp) }\end{array}$ & $\begin{array}{c}\text { Biaya per } \\
\text { Semester/ } \\
\text { per Bulan } \\
\text { (Rp) }\end{array}$ \\
\hline $\begin{array}{l}\text { Jurusan } \\
\text { Sosiologi, FISIP- } \\
\text { UNSOED }\end{array}$ & 2006 & $1,250,000$ & 550,000 \\
\cline { 2 - 4 } UGM & 2008 & $5,000,000$ & $1,100,000$ \\
\hline $\begin{array}{l}\text { SDN 4 } \\
\text { Krandegan } \\
\text { Banjarnegara }\end{array}$ & 2009 & $1,300,000$ & Gratis \\
\hline $\begin{array}{l}\text { SD AL-Irsyad 02 } \\
\text { Purwokerto }\end{array}$ & 2010 & $5,043,000$ & 325,000 \\
\hline
\end{tabular}

Sumber: Berbagai sumber ${ }^{4}$

Tabel 2. Data Standar Pendapatan Perkapita

\begin{tabular}{|c|c|}
\hline $\begin{array}{c}\text { Upah Minimum Regional (UMR) } \\
\text { Provinsi Jawa Tengah } \\
\text { Tahun 2012 }\end{array}$ & $\begin{array}{c}\text { Standar Penghasilan Perkapita } \\
\text { Menurut Bank Dunia Tahun } \\
\mathbf{2 0 1 2}\end{array}$ \\
\hline $\begin{array}{c}\text { Rp. 991.500,- / kapita / bulan. } \\
\text { Atau }\end{array}$ & $\begin{array}{c}\text { USD 2 -PPP (purchasing power } \\
\text { parity) / kapita / hari. } \\
\text { Atau }\end{array}$ \\
Rp. 11.898.000,-/ kapita/ tahun. & USD 730 - PPP (purchasing \\
\hline
\end{tabular}

${ }^{3}$ Ibid

${ }^{4}$ Bapak Hendri R. (Dosen Sosiologi, FISIP-UNSOED), Ibu Rin Rostikawati (Wali Murid SD AL-Irsyad 02 Purwokerto), Koran Sore WAWASAN tanggal 29 Desember 2012, dan http://www.wawasandigital.com/index.php?option=com_content\&task=view\&id=314 $\underline{44 \& \text { Itemid }=61)}$ 
power pariry) / kapita/ tahun.

Sumber : Kementerian Sosial RI ${ }^{5}$

Kedua tabel di atas menunjukkan adanya gap antara kemampuan masyarakat dengan kenyataan yang tak dapat dihindari di hadapan institusi pendidikan saat ini. Bagi seorang buruh pabrik yang dibayar dengan upah minimum, misalnya, menyekolahkan anaknya ke institusi pendidikan saat ini, bisa jadi merupakan langkah yang mesti penuh perhitungan, kalau tidak malah muskil. Pada sisi yang lain, institusi pendidikan tampaknya telah dirasuki nilai-nilai ekonomis: "ada harga ada rupa". Artinya, kemampuan ekonomis masyarakat sangat menentukan ke mana anak-anak akan disekolahkan. Penerimaan institusi pendidikan terhadap calon siswa, sangat ditentukan oleh kemampuan ekonomi orang tuanya. Meski, tidak menutup kemampuan, kualitas calon siswa tetap diperhitungkan oleh sebagian institusi pendidikan. Berangkat dari nilai-nilai ekonomis semacam itu, tidak salah jika masyarakat memandang, misalnya, SD Al-Irsyad merupakan sekolahnya orang-orang the haves atau high class.

"Logika" pelayanan pendidikan saat ini menjadi unik. Karena pelayanan pendidikan yang ada saat ini, kebanyakan tidak lagi melihat seseorang dari kemampuan intelektualnya melainkan hanya melihat persoalan kelas atau golongan, khususnya, dari sisi ekonomis. "Logika" pelayanan pendidikan tersebut tergambar pada tabel berikut.

Tabel 3. "Logika" dunia pendidikan di Indonesia.

\begin{tabular}{|c|c|c|c|}
\hline \multirow{2}{*}{ Kecerdasan } & \multicolumn{3}{|c|}{ Keputusan untuk Sekolah/Tidak Sekolah Berdasarkan } \\
& Atas & Menengah & Bawah \\
\cline { 2 - 4 } Kurang Pintar & Sekolah & $\begin{array}{c}\text { Sekolah / tidak } \\
\text { sekolah }\end{array}$ & $\begin{array}{c}\text { Sekolah / tidak } \\
\text { sekolah }\end{array}$ \\
\hline Sedang & Sekolah & $\begin{array}{c}\text { Sekolah / tidak } \\
\text { sekolah }\end{array}$ & $\begin{array}{c}\text { Sekolah / tidak } \\
\text { sekolah }\end{array}$ \\
\hline Pintar & Sekolah & $\begin{array}{c}\text { Sekolah / tidak } \\
\text { sekolah }\end{array}$ & $\begin{array}{c}\text { Sekolah / tidak } \\
\text { sekolah }\end{array}$ \\
\hline
\end{tabular}

\footnotetext{
5 http://leopratama.com/UMR\%20Indonesia\%202012.pdf. Diakses tanggal 29 Desember 2012.
} 
Berdasarkan tabel tersebut di atas dapat dilihat bahwa "logika" dalam dunia pendidikan di Indonesia masih didasarkan pada masalah materil semata. Orang-orang yang berasal dari keluarga atau status sosial ekonomi atas, akan tetap dapat bersekolah walau seperti apapun tingkat kecerdasannya. Mereka ini memiliki kemampuan untuk membayar biaya pendidikannya. Namun untuk masyarakat kelas menengah dan bawah, tidak jelas benar apakah bisa sekolah, melanjutkan pendidikan, atau tidak. Seseorang yang berasal dari keluarga kelas bawah - yang pendapatannya diukur hanya setinggi UMR/UMP - mungkin saja ia tetap dapat bersekolah atau melanjutkan pendidikan, jika ia memperoleh beasiswa, misalnya. Persoalannya, informasi tentang beasiswa semacam itu tidak mesti dapat diakses. Lebih dari itu, di mana pun, beasiswa selalu bersifat kompetitif. Artinya, tidak semua orang yang mengajukan permohonan dapat memperolehnya. Disinilah, ketidakpastian tersebut. Padahal Undang-Undang Republik Indonesia Nomor 20 Tahun 2003 Tentang Sistem Pendidikan Nasional Bab IV Bagian Kesatu Tentang Hak dan Kewajiban Warga Negara Pasal 5 Ayat 1-5, menjelaskan bahwa:

1. Setiap warga negara mempunyai hak yang sama untuk memperoleh pendidikan yang bermutu.

2. Warga negara yang memiliki kelainan fisik, emosional, mental, intelektual, dan/atau sosial berhak memperoleh pendidikan khusus.

3. Warga negara di daerah terpencil atau terbelakang serta masyarakat adat yang terpencil berhak memperoleh pendidikan layanan khusus.

4. Warga negara yang memiliki potensi kecerdasan dan bakat istimewa berhak memperoleh pendidikan khusus.

5. Setiap warga negara berhak mendapat kesempatan meningkatkan pendidikan sepanjang hayat. ${ }^{6}$

Disinilah, tampaknya, dapat dimaklumi jika banyak orang memandang bahwa pemerintah belum mampu mewujudkan hak-hak warga negaranya akan pendidikan. Bahkan, tidak sedikit orang yang sepakat bahwa pendidikan memang tidak diperuntukkan bagi rakyat kelas ekonomi menengah ke bawah.

${ }^{6}$ UU RI No.20 Tahun 2003 Tentang Sistem Pendidikan Nasional. (http://www.samudrastudio.com/html/FTP/sisdiknas.pdf). Diakses pada Sabtu, 29 Desember 2012. 
Harus diakui bahwa sekolah murah atau bahkan gratis ada. Namun demikian, gratisnya biaya pendidikan tidak serta merta diikuti oleh kualitas pendidikan yang baik pula. Di Indonesia sendiri, tidak ada jaminan bahwa sekolah murah atau gratis akan menjamin kualitas pendidikan di dalamnya. Berikut ini beberapa gambar prasarana dan sarana pendidikan di beberapa tempat di Indone
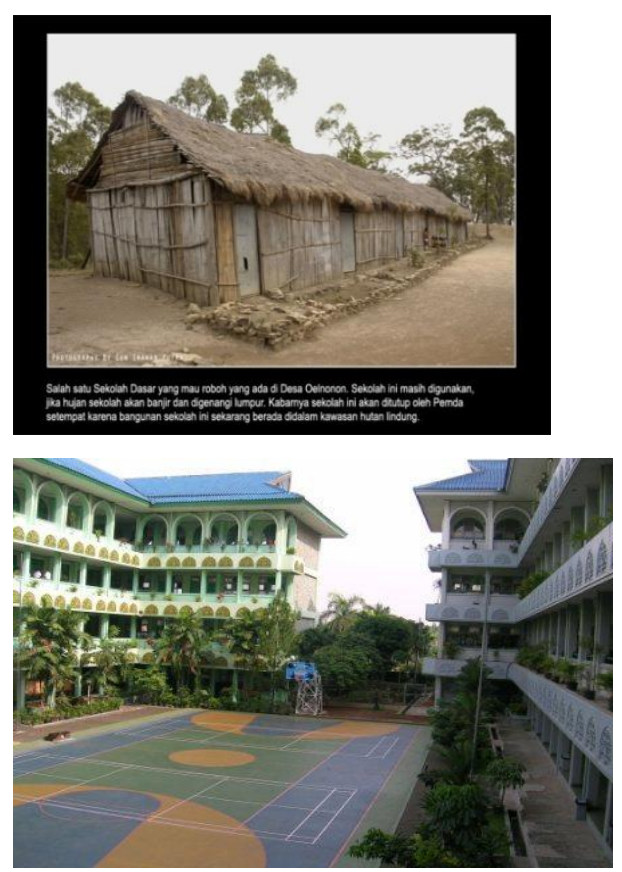

Gambar $1 .^{7}$

Gambar $2 .^{8}$

${ }^{7}$ Gambar salah satu bangunan sekolah di Pulau Timor. http://berangberang.blog.friendster.com/. Diakses pada Sabtu, 29 Desember 2012.

${ }^{8}$ Salah satu gedung sekolah SD Al-Azhar di Bekasihttp://alazhar.syifabudi.sch.id/. Diakses pada Sabtu, 29 Desember 2012. 

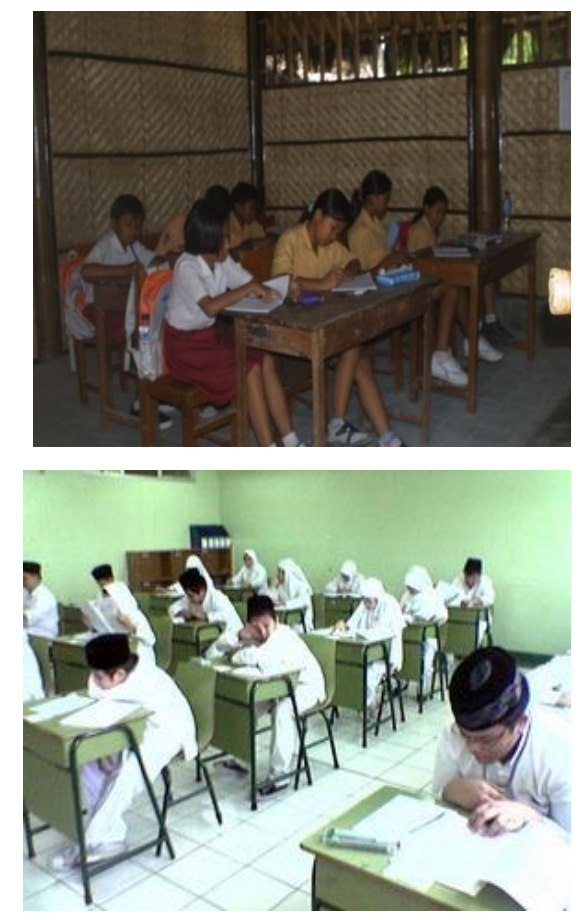

Gambar 3. ${ }^{9}$

Gambar $4^{10}$

Beberapa tahun ini, dengan adanya program bantuan operasional sekolah (BOS), membuat siswa SD dan SMP di seluruh Indonesia tidak perlu membayar iuran sekolah. Dana BOS yang merupakan Dana Bantuan Operasional Sekolah ini diluncurkan pada tahun 2005. Dana BOS merupakan sumber dana utama untuk segala macam kegiatan operasional di sekolah. Dana BOS diadakan dengan tujuan meningkatkan mutu pendidikan di Indonesia, terutama dalam mewujudkan Wajib Belajar Sembilan Tahun. Dana BOS diadakan untuk tujuan penyediaan dana operasional bagi satuan pendidikan, alokasinya bukan untuk gaji guru, melainkan untuk pengadaan sarana dan prasarana pendidikan, peralatan penunjang pendidikan, dan biaya tak langsung lainnya. Dengan penyaluran Dana BOS, semua pendidikan dasar wajib menggratiskan para siswa dari pungutan operasional. Selain untuk meningkatkan mutu pendidikan menjadi lebih baik, Dana BOS juga untuk meringankan beban orang tua siswa. Seyogyanya, BOS mampu membuat sekolah menjadi gratis. Namun, kenyataannya ada saja iuran ini dan itu, sehingga siswa tetap harus mengeluarkan uang seperti

9 Ruang kelas disalah satu sekolah di Pulau Timor.

${ }^{10}$ Ruang kelas di salah satu SD Al-Azhar di Bekasi. 
sebelum program BOS diberlakukan. Bahkan tidak jarang iuran-iuran tersebut sangat memberatkan para orang tua.

Selain mengakibatkan kesenjangan sosial yang semakin besar di antara generasi muda di Indonesia, mahalnya biaya sekolah juga telah mengakibatkan jumlah anak putus sekolah dan anak yang tidak mampu sekolah makin meningkat dari tahun ke tahun. Menurut data resmi yang dihimpun dari 33 Kantor Komnas Perlindungan Anak (PA) di 33 provinsi, jumlah anak putus sekolah pada tahun 2007 sudah mencapai 11,7 juta jiwa. Jumlah itu bisa jadi bertambah lagi tahun ini, mengingat keadaan ekonomi nasional yang kian memburuk. ${ }^{11}$

\section{B. Perspektif Sosiologi dalam Dunia Pendidikan di Indonesia.}

Berbicara mengenai kemiskinan dan pendidikan, mungkin tidak akan pernah ada habisnya. Kedua hal tersebut seolah membentuk rangkaian yang sulit untuk dipisahkan. Kemiskinan telah membuat orang-orang di dalamnya sulit untuk mengenyam pendidikan yang biayanya semakin merangkak naik. Sementara itu, mahalnya biaya pendidikan telah membuat banyak anak putus sekolah bahkan mungkin tidak pernah bisa mengenyam pendidikan. Karena itulah, Samuel Bowles menyatakan bahwa pendidikan hanya berfungsi sebagai mesin reproduksi sistem sosial, dimana pendidikan dijadikan media oleh orangorang miskin dan tidak pandai untuk "mentransendensi" posisi kelas sosial mereka ketika mereka dewasa. ${ }^{12}$ Sehingga dapat dikatakan bahwa, tingkat sosial ekonomi seorang individu akan mempengaruhi tingkat pendidikannya. Hal tersebut dikarenakan, institusi pendidikan yang ada saat ini, cenderung tidak bisa memproduksi atau mengubah status sosial seorang individu dalam hal ini adalah orang-orang miskin. Pendidikan hanya mereproduksi sistem sosial yang ada saat ini, dimana orang-orang miskin hanya dapat bersekolah di sekolah miskin, yang pada akhirnya akan tetap menjadikan mereka sebagai orang miskin.

Dalam pendidikan berbasis Marxis-Sosialis, tujuan (ideologi) pendidikan adalah membangun karakter (character building) manusia yang tercerahkan; suatu kondisi mental yang dibutuhkan untuk membangun suatu masyarakat yang berkarakter progresif, egaliter,

\footnotetext{
${ }^{11}$ Manurung, Robert. 2008. 12 Juta Anak Indonesia Putus Sekolah. (http://ayomerdeka.wordpress.com/2008/03/22/12-juta-anak-indonesia-putussekolah/). Diakses pada Sabtu, 29 Desember 2012.

${ }^{12}$ Karabel, Jerome and A.H. Halsey. 1977. Power and Ideology in Education. Oxford University Press. New York. Hal. 137-153.
} 
demokratis, berkeadilan dan berpihak terhadap kaum-kaum tertindas (the oppressed). ${ }^{13}$ Marx mengidealkan terciptanya pendidikan kritis (critical pedagogy), pendidikan radikal (radical education) dan pendidikan revolusioner (revolutionary education) yang pada gilirannya mampu mencetak manusia yang betul-betul mau memperjuangkan kaum-kaum miskin. Pendidikan yang terjebak pada pragmatisme untuk kepentingan kapitalisme merupakan eksploitasi atas esensi terbentuknya lembaga pendidikan. Menurut Marx, pendidikan bukan lahan basah untuk merenggut keuntungan, melainkan sebagai instrumen membebaskan manusia dari belenggu dehumanisasi serta menempatkan manusia dalam esensi dan martabat kemanusiaannya yang sejati.

Tuntutan era globalisasi, mendorong berkembangnya pola pendidikan Indonesia ke arah pendidikan yang materialistik. Kondisi ini telah memicu pergeseran paradigma pendidikan di segala aspek terutama yang terkait dengan refleksi pendidikan, yang pada hakekatnya harus mengutamakan kebutuhan peserta didik. Esensi pendidikan baik dalam keluarga, masyarakat, maupun sekolah - sebagai satu-satunya jalur yang dapat ditempuh untuk mencetak generasi yang akan mengukir profil atau status atau karakter bangsa Indonesia di era moderen ini - nampaknya mulai mengalami kemunduran. Jaminan bahwa setiap anak akan mendapat pendidikan yang baik dan benar masih perlu dipertanyakan. Isnaeni dalam blognya menyatakan bahwa, tata sosial yang kapitalissekuler menyajikan menu individualis dan materialis yang harus disantap oleh para generasi mulai bayi, balita, anak-anak sampai dewasa. Dunia pendidikan memiliki andil yang tidak kecil terkait krisis multidimensi, karena tidak mampu melahirkan pribadi-pribadi utuh yang mampu menyelesaikan problematika bangsa. ${ }^{14}$.

Realita sehari-hari sering terdengar tentang pendidikan yang berkualitas selalu identik dengan biaya mahal atau tidak gratis. Misalnya, di Yogyakarta pada tahun 2006, biaya seorang anak untuk masuk TK dan SD saja saat itu membutuhkan biaya Rp 500 ribu sampai

${ }^{13}$ http://esaipolitiknurani.blogspot.com/2009/01/resensi-buku-pendidikan-marxissosialis.html. diakses pada Sabtu, 29 Desember 2012.

${ }^{14}$ http://isnaeni.blog.unair.ac.id/2009/08/06/potret-pendidikan-di-indonesia/. Diakses pada Sabtu, 29 Desember 2012. 
Rp 1 juta. Bahkan ada yang memungut di atas Rp 1 juta. Sedangkan untuk masuk SLTP atau SMA bisa mencapai Rp 1 juta sampai Rp 5 juta. ${ }^{15}$ Mahalnya biaya pendidikan yang harus dibayar oleh masyarakat yang ingin mengenyam pendidikan, menjadikan pendidikan sebagai barang mahal dan langka untuk sebagian masyarakat Indonesia yang hidup dalam kemiskinan. Besarnya biaya pendidikan yang ada saat ini, telah memaksa orang-orang miskin untuk memilih antara memenuhi kebutuhan sehari-hari mereka, atau mengeluarkan biaya yang tidak sedikit untuk mengenyam pendidikan. Saat ini, pendidikan dengan kualitas yang baik hanya mampu dinikmati oleh orang-orang yang berpunya dalam hal materi. Orang yang punya uang akan bebas menikmati kualitas pendidikan yang baik, sedangkan orang yang tidak mampu atau miskin harus pasrah dengan kualitas pendidikan yang seadanya, tidak berkualitas, dan fasilitas penunjang yang sangat minim. Padahal, pendidikan yang bermutu dan berkualitas baik merupakan hak seluruh anak bangsa, tanpa melihat status sosial-ekonominya dan inilah yang sesungguhnya merupakan janji berkembangnya peradaban dan bangsa.

Rendahnya perhatian pemerintah terhadap sektor pendidikan berdampak pada bobroknya dunia pendidikan di Indonesia dengan adanya praktik komersialisasi dan kapitalisasi pendidikan. Rendahnya anggaran pendidikan yang dikeluarkan oleh pemerintah membuat praktik komersialisasi dan kapitalisasi pendidikan menjadi semakin subur dengan dalih untuk menutup kekurangan biaya operasional yang tidak dipenuhi oleh pemerintah. Membuat pendidikan menjadi berkualitas memang membutuhkan biaya yang tidak sedikit, namun bukan berarti hal itu dapat begitu saja dibebankan kepada masyarakat. Hal tersebut tetap merupakan kewajiban pemerintah yang harus mampu menjamin pendidikan setiap warganya, baik kaya ataupun miskin, tanpa membedakannya.

Pendidikan merupakan tolak ukur kemapanan seseorang. Mulai dari buruh pabrik sampai pejabat di negeri ini mengirimkan anak mereka

15 Bambang Purwoko. Analisis: Orang Miskin Dilarang Sekolah. Yogyakarta, 14 Juli 2006. 
ke sekolah dengan dalih meraih masa depan. Namun tanpa disadari, dunia pendidikan saat ini terbagi menjadi kelas-kelas sosial ekonomi yang berbeda satu dengan lainnya. Sekali lagi, mereka yang mempunyai uang berlebih akan lebih memilih menyekolahkan anak-anaknya ke sekolah di tengah kota, dengan fasilitas dan kualitas yang sangat baik, sementara mereka yang tidak mempunyai banyak uang akan lebih memilih menyekolahkan anak-anaknya di sekolah-sekolah pinggiran dengan fasilitas dan kualitas yang sangat minim. Dengan dana yang sangat minim itu, orang-orang miskin tersebut tidak lagi memikirkan tentang fasilitas dan kualitas sekolah, yang terpenting anak-anaknya dapat mengenyam pendidikan, itu sudah lebih dari cukup untuk mereka. Bambang Purwoko dalam analisisnya, mengungkapkan :

"Kita pernah mengalami saat-saat ketika para birokrat gemar mempersulit urusan rakyat. Jargon yang terkenal saat itu adalah "kalau bisa dipersulit mengapa harus dipermudah?" Kini nampaknya para birokrat sekolah negeri sedang gemar menikmati jargon baru kapitalisasi pendidikan, "kalau bisa dibuat mahal mengapa harus murah?". Jika dalil sesat ini kita telan mentah-mentah, alangkah malangnya nasib rakyat miskin dan mereka yang hidupnya pas-pasan, karena berarti tertutup kemungkinan bagi anaknya untuk menjadi lebih pintar. Tertutup pula peluang bagi anak-anak untuk memperbaiki nasib orang tuanya. Hanya anak-anak kaya yang tinggal dan bersekolah di kota yang memiliki peluang menjadi pintar. Anak-anak miskin dan sekolah di desa akan tertinggal selamanya. Alangkah tidak adilnya dunia pendidikan Indonesia." 16

Pada dasarnya, pendidikan adalah hak dasar setiap warga masyarakat, kaya atau miskin. Pemerintah berkewajiban untuk memastikan bahwa semua warga masyarakat dapat memperoleh akses pendidikan secara mudah dan murah. Namun kenyataan yang ada di masyarakat justru berbanding terbalik dengan esensi pendidikan itu sendiri. Saat ini, masyarakat, terutama dari kalangan bawah atau miskin tidak sanggup membayar biaya pendidikan yang semakin melejit tinggi.

\footnotetext{
${ }^{16}$ Bambang Purwoko. Analisis : Bisnis Sekolah Negeri. Kedaulatan Rakyat, 3 Agustus 2006.
} 
Mereka beranggapan bahwa sekolah adalah barang mahal yang tidak mungkin mereka miliki. Jangankan memiliki pendidikan yang layak, bermimpi untuk dapat bersekolah pun mereka tidak sanggup.

Banyak orang miskin yang merasa bahwa sekolah adalah ladang untuk menghabiskan uang hasil jerih payah mereka. Bukan tanpa alasan mereka berkata begitu. Mahalnya biaya sekolah membuat orang-orang miskin mesti berpikir seribu kali untuk dapat bersekolah yang merupakan salah satu alternativ peretas jalan untuk meninggalkan kemiskinan. Kebodohan telah membuat orang-orang miskin tersebut hidup hanya dalam alam pikiran mereka. Modernisasi tidak berarti apapun bagi mereka selain menambah sulit hidup mereka karena harga yang harus dibayar untuk sebuah modernitas sangatlah mahal. Mereka yang bodoh hanya akan melihat dunia dari satu sudut pandang, mereka tidak menyadari bahwa di luar sana ada begitu banyak kehidupan yang lebih baik lagi.

Modernisasi yang datang ke Indonesia memberikan pengaruh yang cukup besar bagi masyarakat Indonesia sendiri. Modernitas bukan hanya berdampak pada perkembangan teknologi atau fashion belaka. Namun, juga berdampak pada pola pikir masyarakat yang akan semakin maju dan baik. Anthony Giddens menjelaskan konsep modernitas dalam "The Juggernaut of Modernity"17. Giddens menjelaskan bahwa modernitas layaknya sebuah kendaraan besar yang akan terus melaju, menggiring masyarakat untuk terus berlari menuju masa depan. Modernitas akan melindas setiap hal yang tetap berada ditempatnya. Dalam hal ini, setiap manusia yang tidak dapat mengimbangi laju perkembangan jaman akan tertinggal dan akhirnya akan sangat sulit bagi manusia itu untuk mengikuti perkembangan yang terjadi di luar dirinya.

Mahalnya biaya sekolah bukan satu-satunya hambatan seseorang tidak dapat bersekolah. Pragmatisme bahwa sekolah itu tidak penting juga mempengaruhi cara berpikir para orang tua, apakah mereka akan menyekolahkan anak-anaknya ataukah tidak sama sekali. Masalah biaya pun mengikuti sikap pragmatis tersebut, dimana biaya

${ }^{17}$ Ritzer, George. 2000. Sociological Theory. McGraw-Hill Internasional Editions. Singapore. Hlm. 557-558. 
untuk bersekolah tidak hanya biaya untuk membayar sekolah, namun juga biaya untuk membeli perlengkapan sekolah, yang tentu saja tidaklah gratis.

Perlengkapan sekolah, bagi sebagian orang, bukan barang yang murah. Berikut ini tabel harga perlengkapan sekolah per Januari 2011.

Tabel 4. Harga Perlengkapan Sekolah Habis Pakai per Oktober 2012

\begin{tabular}{|c|l|c|}
\hline NO & JENIS PERLENGKAPAN & HARGA SATUAN (Rp.) \\
\hline 1. & Buku Tulis (Sinar Dunia) & 2.495 \\
\hline 2. & Buku Gambar & 2.500 \\
\hline 3. & Pensil 2B & 3.250 \\
\hline 4. & Pulpen Standard-Fine & 1.100 \\
\hline 5. & Penghapus & 1.200 \\
\hline 6. & Rautan & 1.000 \\
\hline 7. & Penggaris & 1.000 \\
\hline \multicolumn{2}{|r|}{ JUMLAH } & $\mathbf{1 2 . 5 4 5}$ \\
\hline
\end{tabular}

Sumber : Kopkun Unsoed

Tabel 5. Harga Perlengkapan Sekolah Tidak Habis Pakai per Oktober 2012

\begin{tabular}{|c|l|c|}
\hline NO & \multicolumn{1}{|c|}{ JENIS PERLENGKAPAN } & HARGA SATUAN (Rp.) \\
\hline 1. & $\begin{array}{l}\text { Seragam Sekolah (1 stel seragam } \\
\text { merah putih) }\end{array}$ & 65.000 \\
\hline 2. & Sepatu & 50.000 \\
\hline 3. & Tas & 50.000 \\
\hline 4. & Buku Bacaan & 10.000 \\
\hline \multicolumn{2}{|c|}{ JUMLAH } & $\mathbf{1 5 5 . 0 0 0}$ \\
\hline
\end{tabular}

Sumber : Toko Perlengkapan Sekolah di Purwokerto.

Berdasarkan tabel di atas, dapat dilihat bahwa biaya untuk membeli perlengkapan sekolah tidaklah sedikit. Mereka yang berasal dari kalangan menengah ke atas, mungkin tidak akan merasakan beban berat karena harus membeli perlengkapan sekolah itu. Namun, bagi orang-orang yang berasal dari kalangan menengah ke bawah, biaya besar yang harus mereka keluarkan untuk membeli perlengkapan sekolah tersebut sangatlah memberatkan bagi mereka. Dalam tabel diungkapkan bahwa harga satu stel seragam sekolah adalah Rp. 65.000, padahal pada kehidupan nyata, anak yang duduk dibangku sekolah dasar (SD) paling tidak membutuhkan 3-4 stel seragam sekolah (seragam 
pramuka, seragam merah-putih, seragam olahraga, seragam identitas sekolah atau local). Maka bisa dibayangkan berapa banyak uang yang harus dikeluarkan hanya untuk membeli seragam-seragam sekolah tersebut. Bagi orang-orang dari kalangan menengah ke bawah, uang yang harus mereka keluarkan untuk membeli seragam sekolah itu sangatlah besar nilainya. Belum lagi ditambah dengan membeli perlengkapan sekolah lainnya. Hal itu akan sangat memberatkan bagi mereka.

Sekolah yang menjadi barang mewah untuk anak-anak miskin tersebut pun bukanlah sekolah yang mempunyai fasilitas lengkap dengan segala kenyamanan yang diberikan demi mendukung proses belajar mengajar. Sekolah yang mereka impikan tidak jarang mempunyai kondisi yang sangat memprihatinkan.

Sungguh tragis ketika kita melihat sebuah bangunan sekolah yang semestinya aman dan nyaman sebagai tempat belajar para penerus bangsa ternyata atapnya berlubang-lubang yang menyebabkan para siswa harus kepanasan ketika matahari bersinar terik atau harus kehujanan ketika cuaca sedang tidak mendukung, harus ditopang dengan bambu agar atapnya tak roboh, dan dindingnya berlubang yang menyebabkan konsentrasi para siswa menurun. Gambar berikut memperlihatkan bagaimana kondisi beberapa sekolah yang rusak namun tetap digunakan sebagai sarana belajar-mengajar para siswa dan guru. 

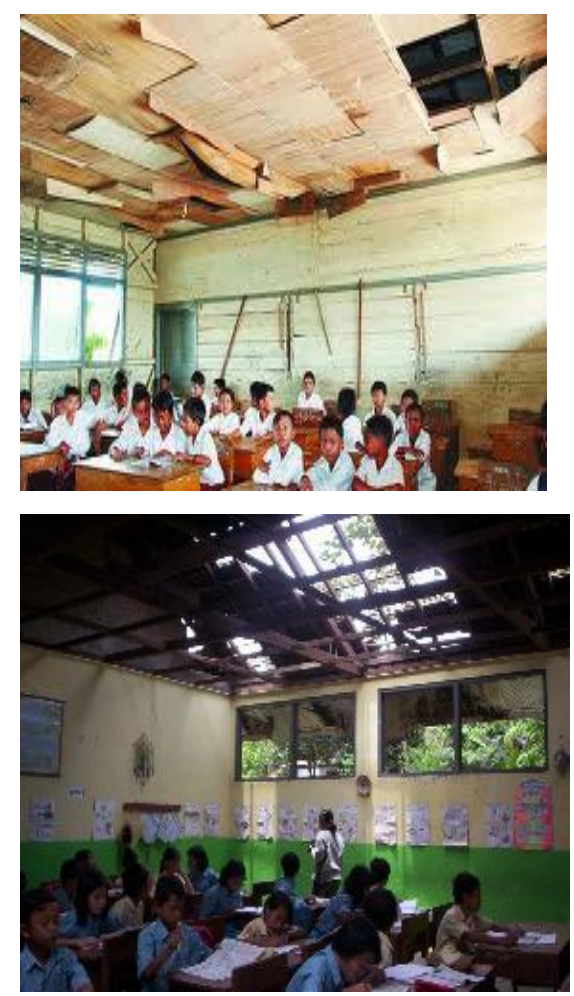

Gambar $6{ }^{18}$

Gambar 7. ${ }^{19}$

${ }^{18}$ Salah satu sekolah dasar (SD) di kota Medan.

http://www.waspada.co.id/index.php?option=com content\&view=article \&id=161505:s ejumlah-sd-ditemukan-rusak-berat\&catid=14\&Itemid=27. Diakses pada Sabtu, 29 Desember 2012.

${ }^{19}$ Sekolah Dasar Negeri di Kecamatan Kepung, Kediri.

http://metro.vivanews.com/news/read/179373-atap-hancur--4-bulan-siswa-belajar-diteras. Diakses pada Sabtu, 20 Desember 2012. 

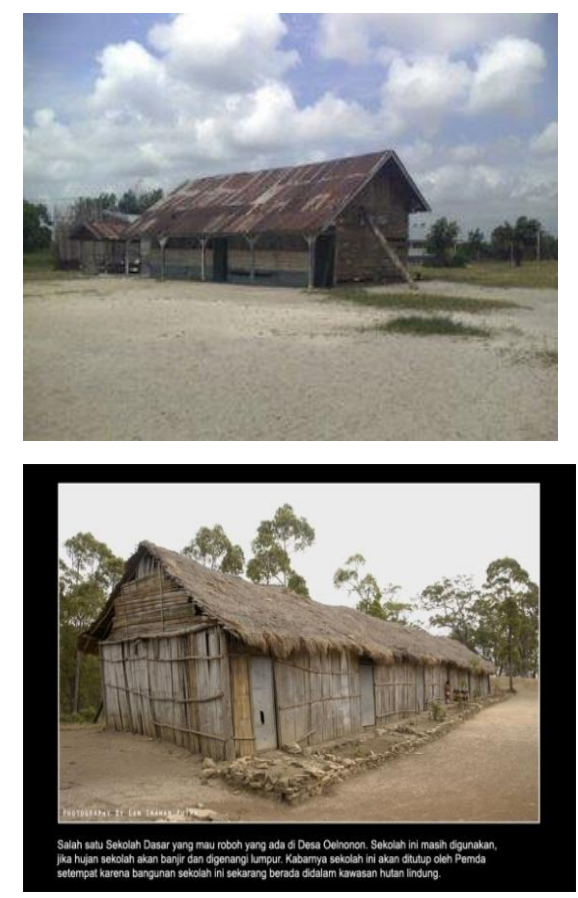

Gambar 8. ${ }^{20}$

Gambar 9. ${ }^{21}$

Berdasarkan data statistik dari Kementerian Pendidikan Nasional, saat ini terdapat sekitar 161.000 gedung sekolah yang rusak. Berdasarkan data tahun 2007/ 2008 gedung Sekolah Dasar rusak sebanyak 139.461, meliputi 72.471 rusak ringan dan 66.990 rusak berat. ${ }^{22}$ Dengan demikian, dapat dilihat bahwa ada peningkatan jumlah sekolah rusak setiap tahunnya.

Sistematisasi pendidikan pun terlihat jelas ketika anak-anak dari kalangan kurang mampu tersebut mulai memasuki dunia pendidikan formal. Kemiskinan dan status sosial mereka menjadi tolak ukur untuk teman-temannya apakah mereka layak atau tidak memasuki lingkungan baru itu.

Berada pada lingkungan yang baru tentu membuat diri kita merasa tidak nyaman. Secara sosiologis, proses adaptasi seseorang ketika masuk dalam suatu lingkungan yang baru dapat dijelaskan dengan

${ }^{20}$ SD Muhammadiyah dalam novel "Laskar Pelangi” karya Andrea Hirata. http://www.wartakota.co.id/read/news/10551\#. Diakses pada Sabtu, 29 Desember 2012

21 Salah satu SD di Pulau Timor. http://berangberang.blog.friendster.com/. Diakses pada Sabtu, 29 Desember 2012.

22 http://www.suaramedia.com/berita-nasional/21471-qribuan-gedung-sekolah-rusak-dprpikirkan-kepentingan-sendiriq.html. diakses pada Sabtu, 29 Desember 2012 
menggunakan Teori Anomi yang dikemukakan oleh Robert K. Merton. Merton menjelaskan keterkaitan antara kelas sosial dengan kecenderungan adaptasi sikap dan perilaku kelompok. Dalam teorinya, Merton mencoba menjelaskan perilaku deviasi dengan membagi norma sosial menjadi 2 (dua) jenis yaitu tujuan sosial (sociate goals) dan sarana yang tersedia (means) ${ }^{23}$. Adanya perbedaan kelas sosial menimbulkan adanya perbedaan tujuan dan sarana yang dipilih. Dengan kata lain struktur sosial yang berbeda-beda dalam bentuk kelas menyebabkan adanya perbedaan kesempatan untuk mencapai tujuan. Kelompok masyarakat kelas bawah atau miskin misalnya memiliki kesempatan yang lebih kecil dibandingkan dengan kelompok masyarakat kelas atas atau kaya. Keadaan tersebut - tidak meratanya kesempatan dan sarana serta perbedaan struktur kesempatan - selanjutnya menimbulkan rasa kecewa pada kelompok bawah atau miskin.

Sekolah sebagai tempat menuntut ilmu memang menjanjikan beberapa hal. Semakin tinggi tingkat pendidikan seseorang, semakin luas pula kesempatan pekerjaan yang bisa didapatkannya. Secara tidak langsung, sekolah menjanjikan masa depan yang lebih baik, jika jenjang pendidikan seseorang bisa terus meningkat.

Pendidikan tidak lagi sama untuk semua orang, namun yang ada saat ini justru pendidikan mulai tersistematisasi dengan amat jelas. Uang atau materi menjadi tolak ukur sebuah lembaga pendidikan dalam mencari siswa-siswanya. Seolah-olah menjadi pintar adalah hak bagi orang-orang yang mempunyai uang yang cukup untuk menyekolahkan anak-anaknya saja. Pendidikan menjadi barang mahal untuk sebagian masyarakat Indonesia. Biaya yang tidak murah, menjadikan pendidikan sulit untuk dijangkau oleh orang-orang dengan kondisi ekonomi lemah.

Pragmatisme kontemporer masyarakat Indonesia saat ini adalah bahwa uang menjajikan kehidupan. Uang adalah instrumen untuk memenuhi kebutuhan material dan non material. Semakin banyaknya jumlah dan jenis kendaraan yang berseliweran di jalan-jalan di kota-kota

${ }^{23}$ http://ceria.bkkbn.go.id/referensi/substansi/detail/120. Diakses pada Sabtu, 29 Desember 2012. 
Indonesia menunjukkan kemampuan masyarakat Indonesia untuk mengumpulkan sejumlah uang untuk membeli alat transportasi modern tersebut. Kekacauan lalu lintas di jalan juga mengindikasikan bahwa masyarakat lebih suka membawa kendaraan sendiri daripada menumpang angkutan umum yang, kondisinya memang, tidak membuat nyaman penumpang. Kendaraan seakan telah menjadi salah satu must have things dalam kehidupan tiap orang. Di sisi yang lain, jumlah calon haji dari Indonesia, misalnya, selalu di atas kuota yang telah ditetapkan oleh pemerintah Arab Saudi. Hal itu menunjukkan bahwa banyak orang Indonesia yang mampu mengumpulkan sejumlah uang yang tidak sedikit untuk melengkapi religiusitasnya. Semakin ruwetnya parkir kendaraan di sekolah-sekolah di kota-kota menegaskan bahwa yang bersekolah di situ adalah mereka yang memiliki uang berkecukupan. Mulai dari kendaraan, haji, dan sekolah, melalui deskripsi tersebut, hanya dapat dipenuhi jika seseorang memiliki sejumlah uang. Di tengah pragmatisme semacam itulah orang tua dari keluarga miskin mesti terseok untuk "menyesuaikan diri”.

Para orang tua dari keluarga miskin saat ini cenderung menempatkan urgensi uang untuk "membeli kehidupan" daripada menyekolahkan anak-anaknya. Mereka akan lebih memilih membelanjakan uang sebesar Rp. $300.000^{24}$ untuk membeli sembako, demi membuat perut mereka menjadi kenyang dan dapat menyambung hidup, daripada untuk menyekolahkan anak-anaknya dengan resiko kelaparan. Tampaknya, telah menjadi "rahasia umum" bahwa uang sebesar Rp. 300.000 tidak akan bisa membuat seorang anak dapat memperoleh pendidikan yang layak dan berkualitas. Hal tersebut membuat orientasi kehidupan orang-orang miskin tersebut berubah: dari janji kebahagiaan (melalui sekolah) melihat masa depan anak-anak yang cerah menjadi sekedar bertahan hidup. Kebahagiaan, bagi keluarga miskin, bukanlah janji dan mimpi. Kebahagiaan adalah mampu makan sehari 1-2 kali, memiliki tempat untuk berteduh dari hujan dan sengatan terik matahari, dan tidak hidup telanjang seperti binatang. Kebahagiaan

${ }^{24}$ Hasil perbincangan dengan salah satu tukang kebun di Desa Bobosan, Purwokerto. 
dengan demikian, adalah bertahan untuk tetap hidup - dan tidak mati kelaparan - dan mempertahankan sisi paling dasar kemanusiaan tempat tinggal dan tubuh yang tertutup pakaian. Inilah pragmatisme yang membatasi ruang gerak anak-anak dari keluarga miskin saat ini.

Orang miskin menjadi sangat tertatih-tatih mengikuti pragmatisme kontemporer masyrakat Indonesia. Orang miskin hanya mampu memenuhi kebutuhan sehari-hari, pun dengan berat karena kabutuhan seperti itu sangat mahal harganya. Berikut adalah tabel harga beberapa kebutuhan sehari-hari per Oktober 2012.

Tabel 6. Harga Kebutuhan Sehari-hari per Oktober 2012.

\begin{tabular}{|l|l|l|}
\hline NO & JENIS BARANG & HARGA (Rp.) \\
\hline 1. & Beras IR & $6.500 / \mathrm{kg}$ \\
\hline 2. & Mie Instan "Supermie" & $950 /$ bungkus \\
\hline 3. & Gula Pasir & $9.500 / \mathrm{kg}$ \\
\hline 4. & Kopi & $15.000 / \mathrm{kg}$ \\
\hline 5. & Minyak Goreng Curah & $9.500 / \mathrm{kg}$ \\
\hline
\end{tabular}

Sumber : Warung Sembako di Desa Bobosan, Purwokerto.

Berdasarkan tabel di atas, dapat dibayangkan berapa banyak jumlah biaya yang harus dikeluarkan oleh setiap keluarga miskin untuk memenuhi kebutuhan sehari-harinya. Jika satu keluarga kecil yang terdiri dari empat orang anggota keluarga (Bapak, Ibu, dan dua orang anak) membutuhkan beras sebanyak $15-20 \mathrm{~kg} / \mathrm{bulan}$, maka setiap bulannya mereka harus mengeluarkan biaya sebesar Rp. 97.500 - Rp. 130.000, hanya untuk membeli beras saja. Belum lagi jika ditambah dengan membeli mie instan, gula pasir, kopi, dan minyak goreng. Maka akan semakin besar pula biaya yang harus mereka keluarkan untuk membeli kebutuhan sehari-harinya.

Makanan adalah needs, bukan something wanted. Makanan, dengan demikian, adalah kebutuhan yang tidak terhindarkan. Jika pengeluaran per bulan setiap orang untuk makanan hampir sebesar Rp 150,000 maka keluarga miskin yang beranggotakan 4 orang mesti mengeluarkan uang sekitar Rp 600,000. Dengan kondisi yang seperti itu, keluarga miskin yang memperoleh pendapatan persis sebesar UMR di Jawa Tengah (Rp.660.00/bulan, lihat Latar Belakang, hal. 3) tidak lagi (mampu) 
berpikir untuk menyekolahkan anak-anaknya. Mereka akhirnya hanya berpikir tentang apa yang dapat menyambung hidup mereka keesokan harinya. Maka, menjadi sangat rasional dan masuk akal ketika orang tua miskin menempatkan pendidikan anak-anaknya dalam pilihan hidup dan mati: jika anak tidak sekolah, hidup, jika anak sekolah, bisa mati kelaparan.

Masalah yang dihadapi oleh anak-anak miskin dalam OMDS, bukan hanya tentang pragmatisme orangtua dan majikan mereka yang tidak setuju mereka bersekolah, namun juga tentang masalah biaya yang pada akhirnya memaksa mereka untuk bekerja membanting tulang demi memenuhi keinginan mereka untuk bersekolah yang memakan biaya tidak sedikit. Persoalan biaya sekolah, bukan hanya tentang biaya SPP, namun juga tentang biaya perlengkapan sekolah yang harus mereka beli. Saat ini, biaya SPP untuk pendidikan 9 tahun memang telah dibebaskan oleh pemerintah. Namun bukan berarti, beban yang harus ditanggung oleh para orangtua untuk menyekolahkan anak-anaknya menjadi lebih ringan. Karena, biaya SPP yang telah dibebaskan itu seolah "bertransformasi" menjadi biaya untuk membeli pakaian seragam, kaos kaki, sepatu, buku tulis, pensil, ball-point, tas sekolah dan sebagainya. Belum lagi, buku bacaan yang hampir setiap semester mesti diperbaharui. Meski sejak tahun 2009 pemerintah telah menggulirkan dana BOS (Biaya Operasional Sekolah) ${ }^{25}$ yang salah satu peruntukkannya adalah untuk memenuhi kebutuhan peserta didik akan buku bacaan, pada tingkat implementasi, tidak semua sekolah yang menyediakan pendidikan wajib 9 tahun (SD dan SMP) mematuhinya. Dengan demikian, masih cukup banyak orang tua murid yang mesti mengeluarkan uang sendiri untuk memenuhi anaknya akan buku bacaan sekolah. Program wajib belajar 9 tahun yang membebaskan peserta didiknya dari biaya operasionalnya, ternyata tidak seluruhnya benarbenar gratis bagi orang tua murid. Persoalan yang dihadapi anak-anak

${ }^{25}$ Direktorat Pembinaan TK dan SD KEMENDIKNAS, http://bos.ditptksd.go.id/index.php?option=com_content\&view=article \&id=56\&Itemid= $\underline{75}$ diakses pada hari Sabtu, 29 Desember 2012. 
tersebut semakin pelik ketika berhadapan dengan pandangan stereotipikal masyarakat kepada orang miskin.

Secara sosiologis, tindakan dan atau perilaku manusia ditentukan oleh status sosial ekonominya. Setidaknya, demikian itu yang diyakini oleh Karl Marx (1818-1883) melalui konsep materialisme historisnya. ${ }^{26}$ Tindakan, perilaku, dan bahkan kehidupan sosial ditentukan oleh materi. Sejarah perkembangan manusia adalah sejarah perkembangan materi. Seorang yang dalam kehidupannya dipenuhi dan difasilitasi dengan kebutuhan-kebutuhan sehari-hari (yang dalam kerangka berfikir Marx tersebut adalah salah satu bentuk materi) yang berlimpah, pertama-tama, akan memiliki pengalaman dan kemudian cara pandang yang berbeda dengan mereka yang serba kekurangan. Melalui cara yang demikian itu pula pandangan stereotipikal (kecurigaan dan atau pandangan negatif) antarkelas sosial ekonomi yang berbeda menyusup. Secara mental dan psikologis, kondisi ekonomi yang lemah, membuat mereka secara tidak langsung akan merasa berbeda dengan teman-temannya yang kondisi ekonominya jauh di atas mereka yang lemah, sehingga dapat mempengaruhi kemampuan mereka ketika bersekolah. Anak-anak miskin yang berhasil melepaskan diri dari sindrom rendah diri ini dan mampu berprestasi dalam pendidikannya, tentu saja, bukan tidak ada. Namun demikian, jumlah yang berhasil tersebut masih jauh lebih sedikit daripada mereka yang terpaksa harus membentengi diri secara psikologis melalui perilaku-perilaku yang tidak semestinya. Tawuran yang melibatkan pelajar SD dan SMP di jalanan Jakarta, tidak hanya dapat dilihat dari adanya perkembangan perilaku kriminal sejak dini melainkan tawuran itu berfungsi sebagai pemersatu bagi siswa-siswa yang berbeda status sosial ekonominya dan di dalam keseharian bisa jadi tidak pernah bertegur sapa.

Pendidikan bukan lagi diorientasikan dan ditujukan untuk mengentaskan kebodohan, tapi telah dijadikan sebagai ladang bisnis bagi sebagian orang. Mereka ini tampaknya tidak lagi peduli pada

\footnotetext{
${ }^{26}$ Lihat dalam Franz Magnis-Suseno, Pemikiran Karl Marx: Dari Sosialisme Utopis ke Perselisihan Revisionisme, PT. Gramedia, Jakarta, 1999, h. 139-142 dan 215-218.
} 
generasi muda bangsa yang butuh pendidikan berkualitas. Akhir-akhir ini, kita banyak dihadapkan pada kenyataan bahwa esensi dunia pendidikan kita telah berubah. Tujuan pendidikan tidaklah hanya mengisi ruang-ruang imajinasi dan intelektual anak, mengasah kepekaan sosialnya, ataupun memperkenalkan mereka pada aspek kecerdasan emosi. Emile Durkheim (1858-1917) ${ }^{27}$ berpendapat bahwa pendidikan adalah suatu social thing, dimana pendidikan bukan hanya satu bentuk, baik dalam artian ideal maupun aktualnya, tetapi bermacam-macam. Menurut Durkheim, pendidikan merupakan alat untuk mengembangkan kesadaran diri dan kesadaran sosial menjadi suatu panduan yang stabil, disiplin, utuh, serta bermakna. Tujuan dan konsep tentang pendidikan seperti diutarakan diatas, saat ini berbanding terbalik dengan kenyataan yang ada.

Saat ini, pendidikan telah menjadi komoditi: segala sesuatu yang dapat diperjualbelikan. Dalam kerangka berfikir Marx, pendidikan telah mengalami proses yang disebut sebagai komodifikasi: segala sesuatu yang tadinya tidak bisa atau tidak layak untuk diperjualbelikan kini dapat dan layak diperjualbelikan. Dalam bukunya Communist Manifesto (1848), Marx mendefinisikan komodifikasi sebagai "Callous Cash Payment": pembayaran tunai yang tidak pantas. ${ }^{28}$ Ia menggambarkan bahwa kaum kapitalis yang mempunyai kontrol atas apapun telah mengubah nilai-nilai personal menjadi nilai tukar. Sehingga segala sesuatu tidak akan bernilai jika tidak mempunyai nilai tukar. Komersialisasi dari aktivitas pendidikan dilakukan melalui tekanan yang disampaikan dalam mekanisme pasar. Segala bentuk aktivitas pendidikan dilakukan semata-mata untuk tujuan komersialisasi, untuk tidak menyebut profit-oriented. Pendidikan kontemporer telah

http://books.google.co.id/books?id=TkqF8C8ffK4C\&pg=PA223\&lpg=PA223\&dq=sosi o-

kultural+durkheim\&source=bl\&ots=OV36VAOgZe\&sig=J_1Nu8Pye2Ui7nvbrB718Mel 7lk\&hl=id\&ei=EGNPTenLJI trQfi39XZBg\&sa=X\&oi=book result\&ct=result\&resnum $=4 \& v e d=0 C C M Q 6 A E w A w \# v=o n e p a g e \& q=$ sosio-kultural \%20durkheim\&f=false.

28 Diakses pada Sabtu, 29 Desember 2012 difikasi_Itu. Diakses pada Sabtu, 29 Desember 2012. 
mengurung tujuan luhur pendidikan itu sendiri sebagaimana yang diungkapkan oleh Durkheim di muka menjadi sekedar "ono rego ono rupo", terminologi Jawa untuk mendeskripsikan interaksi ekonomis: jika anda memiliki uang banyak maka anda akan memperoleh imbal materi yang lebih baik daripada jika uang anda sedikit; dengan perkataan lain, jika uang anda sedikit maka imbal materi yang anda peroleh akan buruk. Sisi human interest pada pendidikan seakan hilang di bawah bayangbayang komodifikasi dan kemersialisasi pendidikan.

Bicara tentang pendidikan di Indonesia seakan tidak akan ada habisnya. Ada begitu banyak masalah pendidikan di negeri ini yang membuat wajah dunia pendidikan semakin buram. Mulai dari kualitas siswa yang masih rendah, pengajar yang kurang profesional, biaya pendidikan yang mahal, bahkan aturan UU Pendidikan yang kacau. Kenyataan yang dapat kita lihat bahwa banyak di daerah-daerah pinggiran yang tidak memiliki sarana pendidikan yang memadai. Dengan terbengkalainya program wajib belajar sembilan tahun mengakibatkan anak-anak Indonesia masih banyak yang putus sekolah sebelum mereka menyelesaikan wajib belajar sembilan tahun. Dengan kondisi tersebut, bila tidak ada perubahan kebijakan yang signifikan dari pemerintah, maka sulit bagi bangsa ini keluar dari masalah-masalah pendidikan yang ada, apalagi bertahan pada kompetisi di era global.

Sekolah-sekolah gratis di Indonesia seharusnya memiliki fasilitas yang memadai, staf pengajar yang berkompeten, kurikulum yang tepat, dan memiliki sistem administrasi dan birokrasi yang baik dan tidak berbelit-belit. Akan tetapi, pada kenyataannya, sekolah-sekolah gratis adalah sekolah yang terdapat di daerah terpencil yang kumuh dan segala sesuatunya tidak dapat menunjang bangku persekolahan sehingga timbul pertanyaan ,"Benarkah sekolah tersebut gratis? Kalaupun gratis, wajar karena kondisinya yang sangat memprihatinkan. Siapa yang mau sekolah disana??"

Pendidikan berkualitas memang tidak mungkin murah, atau tepatnya, tidak harus murah atau gratis. Tetapi persoalannya siapa yang 
seharusnya membayarnya? Pemerintahlah sebenarnya yang berkewajiban untuk menjamin setiap warganya memperoleh pendidikan dan menjamin akses masyarakat miskin untuk mendapatkan pendidikan bermutu. Akan tetapi, kenyataannya, pemerintah justru ingin berkilah dari tanggung jawabnya. Padahal, keterbatasan dana tidak dapat dijadikan alasan bagi Pemerintah untuk cuci tangan dalam masalah pendidikan yang semakin rumit setiap harinya. Sesungguhnya, bukan tidak ada dana untuk mensubsidi pendidikan melainkan ketiadaan political will elit politik penentu kebijakan di negeri ini serta penanganan dana pendidikan yang tidak profesional sehingga dana tersebut hanya tersebar di seputar ibu kota Negara.

\section{Kesimpulan dan Implikasi.}

\section{Kesimpulan.}

Pendidikan dan kemiskinan adalah dua hal yang saling terkait. Pendidikan seharusnya menjadi hak bagi setiap orang tanpa memandang kaya-miskin seseorang. Namun kenyataannya, pendidikan yang seharusnya menjadi jalur bagi masyarakat miskin untuk dapat memperbaiki kehidupannya, nyatanya tidak dapat berbuat apa-apa ketika orang-orang miskin tersebut justru tersingkirkan darinya dan tidak dapat menggapainya. Ketidakadilan dalam dunia pendidikan semakin terlihat jelas dengan adanya sistematisasi pendidikan, dimana akhirnya terjadi gap antara kelompok orang-orang kaya dan kelompok orang-orang miskin dalam dunia pendidikan. Mereka yang berasal dari keluarga kaya, akan dengan mudah mengakses pendidikan yang berkualitas baik. Sedangkan orang-orang yang berasal dari kalangan menengah ke bawah, harus bekerja keras dan berjuang demi mendapatkan pendidikan yang layak untuk dirinya, keluarga, dan anak-anaknya. Terminology Jawa "ono rego ono rupa" telah menjadi slogan baru dalam dunia pendidikan. Maka tidaklah mengherankan, ketika orang-orang miskin yang berhasil mengenyam pendidikan formal, tetap menjadi miskin (meskipun ada beberapa yang akhirnya sukses merubah hidupnya). Hal tersebut dikarenakan pendidikan yang didapatnya adalah pendidikan yang seadanya, yang jauh dari fasilitas memadai, bahkan dengan kualitas 
yang masih perlu dipertanyakan kelayakannya. Jauh berbeda dengan orang-orang yang mempunyai banyak uang yang dapat bersekolah disekolah dengan fasilitas yang memadai, dan kualitas yang baik.

Sistematisasi kemiskinan dan pendidikan yana terjadi dalam masyarakat sebagai berikut :

- Orang miskin mempunyai peluang yang lebih sedikit dalam kesempatan untuk memperoleh pendidikan, dibandingkan dengan orang-orang kaya. Bukan hanya karena biaya yang harus dikeluarkan untuk mengenyam pendidikan yang tidak murah, tetapi juga karena pragmatisme masyarakat umum yang menganggap bahwa orang miskin tidak layak untuk sekolah karena sekolah tidak akan bisa merubah hidup mereka menjadi lebih baik. Mereka justru akan semakin miskin karena biaya yang dikeluarkan untuk sekolah tidaklah sedikit.

- Kemiskinan membuat sebagaian orang enggan mengenyam pendidikan, karena pola pikir mereka yang menganggap bahwa sekolah tidaklah penting dan hanya membuang-buang uang saja.

- Biaya pendidikan yang mahal semakin membuat masyarakat miskin sulit untuk menggapai dunia pendidikan itu sendiri. Mereka harus bekerja dan berjuang keras agar dapat mengenyam pendidikan yang layak.

- Kurangnya perhatian pemerintah dan lembaga pendidikan terhadap sarana dan prasarana pendidikan, membuat proses kegiatan belajar mengajar menjadi tidak maksimal. Hal itu juga mengganggu konsentrasi para peserta didik.

Peluang atau kesempatan orang-orang miskin dalam dunia pendidikan haruslah sama. Hal tersebut dapat terjadi jika ada dukungan dari pemerintah, lembaga pendidikan, dan masyarakat umum baik kaya maupun miskin. Mereka diharapkan dapat bekerjasama agar tidak ada lagi sistematisasi kemiskinan dan pendidikan di negeri ini.

\section{Implikasi}


- Peluang memperoleh pendidikan untuk masyarakat miskin harus diperbesar agar masyarakat miskin dapat memperoleh haknya dalam bidang pendidikan. Salah satu caranya adalah dengan memberikan pendidikan atau sekolah gratis untuk masyarakat miskin, dengan fasilitas dan kualitas yang baik.

- Melakukan pendekatan personal dengan orang tua keluarga miskin, dan memberi pemahaman pada mereka agar pola pikir mereka berubah, bahwa pendidikan penting untuk anak-anak mereka. Sehingga mereka mau menyekolahkan anak-anaknya.

- Pemerintah harus menekan biaya pendidikan yang semakin melambung tinggi, agar masyarakat miskin mampu menjangkau pendidikan. Sehingga tidak ada lagi alasan tidak sekolah, karena sekolah itu mahal dan hanya membuang-buang uang saja.

- Perbaikan sarana dan prasarana pendidikan akan membuat proses belajar mengajar menjadi maksimal. Konsentrasi siswa yang tidak terganggu akan membuat kualitas siswa menjadi lebih baik lagi.

\section{DAFTAR PUSTAKA}

Abdullah, M. Amin dkk. 2000. Antologi Studi Islam (teori dan metodologi). Dip PTA IAIN Sunan Kalijaga. Yogyakarta

Bungin, Burhan. 2008. Penelitian Kualitatif : Komunikasi, Ekonomi, Kebijakan Publik dan Ilmu Sosial lainnya. Cetakan kedua. Kencana. Jakarta

Faruk. 1994. Pengantar Sosiologi Sastra. Pustaka Pelajar. Yogyakarta

Freire, Paulo. 2003. Menggugat Pendidikan : Fundametalisme, Konservatif, Liberal, Anarkis. Pustaka Pelajar. Jakarta

Gadamer, Hans Georg. 2004. Kebenaran dan Metode. Pustaka Pelajar. Jakarta

Karabel, Jerome and A.H. Halsey. 1977. Power and Ideology in Education. Oxford University Press. New York. Hal. 137-153.

Nasution, S. 1983. Sosiologi Pendidikan. Penerbit Jemmars. Bandung 
Palmer, E. Richard. 2005. Hermeneutika: Teori Baru Mengenai Interpretasi. Pustaka Pelajar. Jakarta

Prasetyo, Wiwid. 2010. Orang Miskin Dilarang Sekolah (mimpi-mimpi tak terjamah). Diva Press. Yogyakarta

Russel, Bertrand. 1993. Pendidikan dan Tatanan Sosial. Yayasan Obor Indonesia. Jakarta

Sumaryono, E. 2009. Hermeneuti, Sebuah Metode Filsafat. Kanisius. Yogyakarta

Sastra dan Pendidikan. Materi kuliah sosiologi sastra jurusan sosiologi, Fisip-Unsoed. 2010.

\section{Sumber Lain :}

Definisi Pendidikan. (http://www.scribd.com/doc/7592955/DefinisiPendidikan). Diakses pada Senin, 29 Oktober 2012.

Ilham, Wika Y, 10 Desember 2007. Realita dan Idealisme Pendidikan Nasional. http://scientiarum.com/2007/12/10/potret-pendidikannasional-realita-dan-idealisme/. Diakses pada Senin, 29 Oktober 2012.

KementerianSosialRI.2010.http://www.depsos.go.id/modules.php?name=Ne $\underline{\text { ws\&file }=\text { article\&sid=629. }}$. Diakses pada Senin, 29 Oktober 2012.

Manurung, Robert. 22 Maret 2008. 12 Juta Anak Indonesia Putus Sekolah. http://ayomerdeka.wordpress.com/2008/03/22/12-juta-anakindonesia-putus-sekolah/. Diakses pada Senin, 29 Oktober 2012.

Seriyawati, Lizsa Anggraeni. 2009. Kandungan Nilai Pendidikan Dalam Novel Menyemai Cinta di Negeri Sakura. http://organisasi.org/kandungan-nilai-pendidikan-dalam-novelmenyemai-cinta-di-negeri-sakura. Diakses pada Senin, 29 Oktober 2012.

UU RI No.20 Tahun 2003 Tentang Sistem Pendidikan Nasional. http://www.samudra-studio.com/html/FTP/sisdiknas.pdf.Diakses pada Senin, 29 Oktober 2012.

http://esaipolitiknurani.blogspot.com/2009/01/resensi-buku-pendidikanmarxis-sosialis.html. Diakses pada Senin, 29 Oktober 2012. http://kepri-dev.bps.go.id/en/description-a-terms/84-penjelasan-teknis/100kemiskinan. diakses pada Senin, 29 Oktober 2012. 
http://www.kontan.co.id/index.php/nasional/news/8438/Tahun-Ini-Orang-

Miskin-di-Indonesia-337-Juta-Orang. diakses pada Senin, 29 Oktober 2012 . 